\title{
BUTTERFLIES FROM THE UBERLÂNDIA REGION, CENTRAL BRAZIL: SPECIES LIST AND BIOLOGICAL COMMENTS
}

\author{
MOTTA, P. C. \\ Departamento de Zoologia, Universidade de Brasília, CEP 70910-900, Brasília, DF, Brazil \\ Correspondence to: Paulo César Motta, Departamento de Zoologia, Universidade de Brasília, \\ CEP 70910-900, Brasília, DF, Brazil, e-mail: mottapc@unb.br \\ Received October 9, 2000 - Accepted May 17, 2001 - Distributed February 28, 2002
}

\begin{abstract}
A total of 251 butterfly species were recorded in Uberlândia region, with collecting concentrated mainly in forest areas. Aspects of geographic distribution of some Ithomiinae, as well as interactions of both adults and immatures with plants, and reproduction periods for the more abundant species are discussed. Collections in open, riverside, and wetland areas, as well as the use of bait, should substantially increase the number of species.
\end{abstract}

Key words: butterfly, Lepidoptera, Ithomiinae, diversity, cerrado, mesophytic forest.

\section{RESUMO}

\section{Borboletas da região de Uberlândia, Brasil Central: lista de espécies e comentários biológicos}

Foram registradas 251 espécies de borboletas em Uberlândia, sendo a ênfase da coleta em áreas de mata. São abordados aspectos da distribuição geográfica de alguns Ithomiinae, bem como as interações de adultos e imaturos com plantas e períodos de reprodução das espécies mais abundantes. Coletas em ambientes abertos, beira de rio, brejos e a utilização de iscas aumentarão substancialmente o número de espécies.

Palavras-chave: borboleta, Lepidoptera, Ithomiinae, diversidade, cerrado, mata mesófila

\section{INTRODUCTION}

Butterflies are considered to be the most beautiful insects and represent archetypes of feelings such as renewal or rebirth. These insects are members of one of the largest animal orders (Lepidoptera), and maintain close relationships with plants: caterpillars are herbivores, and adults of most species are potential pollinators. "Disgusting" caterpillars become butterflies. Beautiful and fluttering, they are also exposed and static, like souvenirs. They are attractive, but also toxic, as predators like birds and spiders know well. They are light, but their majestic flight disguises an inebriate state induced by nectar or fermented fruits. Butterflies are, therefore, ambiguous beings and objects of investigation in a wide range of ecological and evolutionary studies. Mimicry and camouflage, insect-plant interactions (herbivory, pollination, coevolution, and the chemical components involved), migration, speciation, extinction, population genetic variability, and biogeographic patterns are examples of subjects concerning which relevant work has involved butterflies.

In the final decades of the twentieth century, there has been a strong interest in conservation of natural habitats. One of the criteria used for inventory of environmental preservation areas is taxonomic biodiversity (number of species), and butterflies help to quantify the environmental quality of a determined area, since they are excellent indicators for the choice of conservation units (see Brown \& Brown, 1992; Brown, 1996a,b,c, 1997; New et al., 1995; Solis \& Pogue, 1999).

The importance of a regional species list, in the case of butterflies, is that it provides, explicitly 
or not, information about genetic and ecological diversity as well as taxonomic diversity.

Around 3300 butterfly species occur in Brazil (Brown, 1996b). Six hundred twenty-eight butterfly species have been collected from the Brazilian Central Plateau (Brown \& Mielke, 1967a,b). However, the present total number known is around one thousand (K. Brown, pers. comm.).

From the list compiled by Brown \& Mielke (1967a,b), only 2 species from Uberlândia are included, plus 1 collected in Uberlândia and Araguari and 42 in Araguari, a city approximately $30 \mathrm{~km}$ to the north of Uberlândia. All of them were collected at the beginning of the 1930s by Roberto Spitz and deposited in German and Austrian museums, with some taxa represented by specimens in Brazilian museums (Mielke \& Casagrande, 1988).

The objective of this study was to make a preliminary inventory, through field collections and bibliographic review, of the butterfly species occurring in the Uberlândia region. Ecological and biogeographic aspects for the more abundant forest species are discussed.

\section{MATERIALS AND METHODS}

\section{Study area}

The city of Uberlândia ( $18^{\circ} 57^{\prime} \mathrm{S}, 48^{\circ} 12^{\prime} \mathrm{W}$, altitude around $800 \mathrm{~m}$ ) is located in the cerrado region, at the southern limits of the Brazilian Central Plateau, in southwestern Minas Gerais, near the northern border of the Paraná River sedimentary basin.

The hydrographic basins of the Uberabinha and Araguari rivers contribute to the River Plate watershed (Brown \& Mielke, 1967a). The climate, following the classification system of Köppen, is Aw (Rosa et al., 1991), characterized more by precipitation than temperature, with a dry season from mid-May until mid-September, and a rainy season during the rest of the year.

The areas visited include the Sabiá Park, Agricultural School, Sucupira Falls, Panga Ecological Park, Miranda Hydroelectric Unit, the Marileuza Farm, and the São José Farm.

The principal area visited was a fragment of mesophytic, semideciduous forest, of approximately 30 ha, on the Glória Farm, owned by the Universidade Federal de Uberlândia, $12 \mathrm{~km}$ from the center of Uberlândia (near the BR 050 highway, which connects São Paulo to Brasília).
The Glória forest fragment is in a swampy depression, with mild slopes. After a stretch of 3 $\mathrm{km}$, the small streams formed by the confluence of waters seeping from the springs flow into the Uberabinha River (Paranaíba River basin and, later, the Paraná River).

Within this forest there is, at least in the herbshrub stratum, a difference in species composition, probably related with the slope and soil humidity.

Rubiaceae predominates principally Psychotria spp. in the drier areas, and ferns in the more humid areas (for arboreal species, see Araújo \& Haridasan, 1997).

Along with those in forest habitats (mesophytic or gallery) but less intensively, collections were made in cerrado (stricto sensu) and in urban habitats.

\section{Data collection}

Collections were made monthly, from March, 1990 to March, 1994. Butterflies were captured with entomological nets or, less frequently, with traps, using fermented sugarcane juice and bananas.

Additional information on species occurrence was obtained from Brown \& Mielke (1967a,b), A. Ruszczyk and collaborators (pers. comm.), and Ruszczyk \& Silva (1997).

All species were identified by Dr. Keith Brown Jr., of the Universidade Estadual de Campinas.

Specimens collected are now deposited in the Museu de Entomologia da Universidade de Brasília. Photographs of the principal species may be found in DeVries (1987) and Brown (1992). Sbordoni \& Forestiero (1985) present a general illustrated view of lepidopterans.

The classification adopted for Nymphalidae follows Scott (1985) and Harvey (1991), and for Papilionidae, Tyler et al. (1994).

\section{RESULTS AND DISCUSSION}

\section{Species list}

One hundred fifty-eight species were collected that, when added to the 93 records cited in the literature, gave 251 butterfly species for the Uberlândia region (Table 1), with 110 species of Nymphalidae, 64 Lycaenidae, 52 Hesperiidae, 17 Pieridae, and 8 Papilionidae.

Of the species recorded from the collecting areas, 75 were collected in urban environments, though not exclusively. 
TABLE 1

List of butterflies collected in Uberlândia region (MG). Codes following the name of the species' author (between [ ]) represent the collector or information source and the collection site. Collectors: 1 (P. C. Motta), 2 (Brown \& Mielke, 1967a,b, Araguari/MG), 3 (Brown \& Mielke, 1967a,b, Uberlândia/MG), 4 (Alexandre Ruszczyk, Élvis Souza Nascimento and Hamilton Garcia Jr., pers. comm., in forest areas), 5 (Ruszczyk \& Silva, 1997, in urban environments), 6 (Araújo et al., 1987, in Uberaba/MG, forest areas) and 7 (Mielke \& Casagrande, 1988, Araguari/MG). Habitat (collector number 1): a (open area, grassland, cerrado, forest edge, wetland), $\mathbf{m}$ (mesophytic or gallery forest), u (urban area). The species marked with "**" are not included in the lists of Brown \& Mielke (1967a,b) for the Central Plateau, and those marked with "+" or "\#”, are in the northwest or south distribution limit, respectively (K. Brown, pers. comm.).

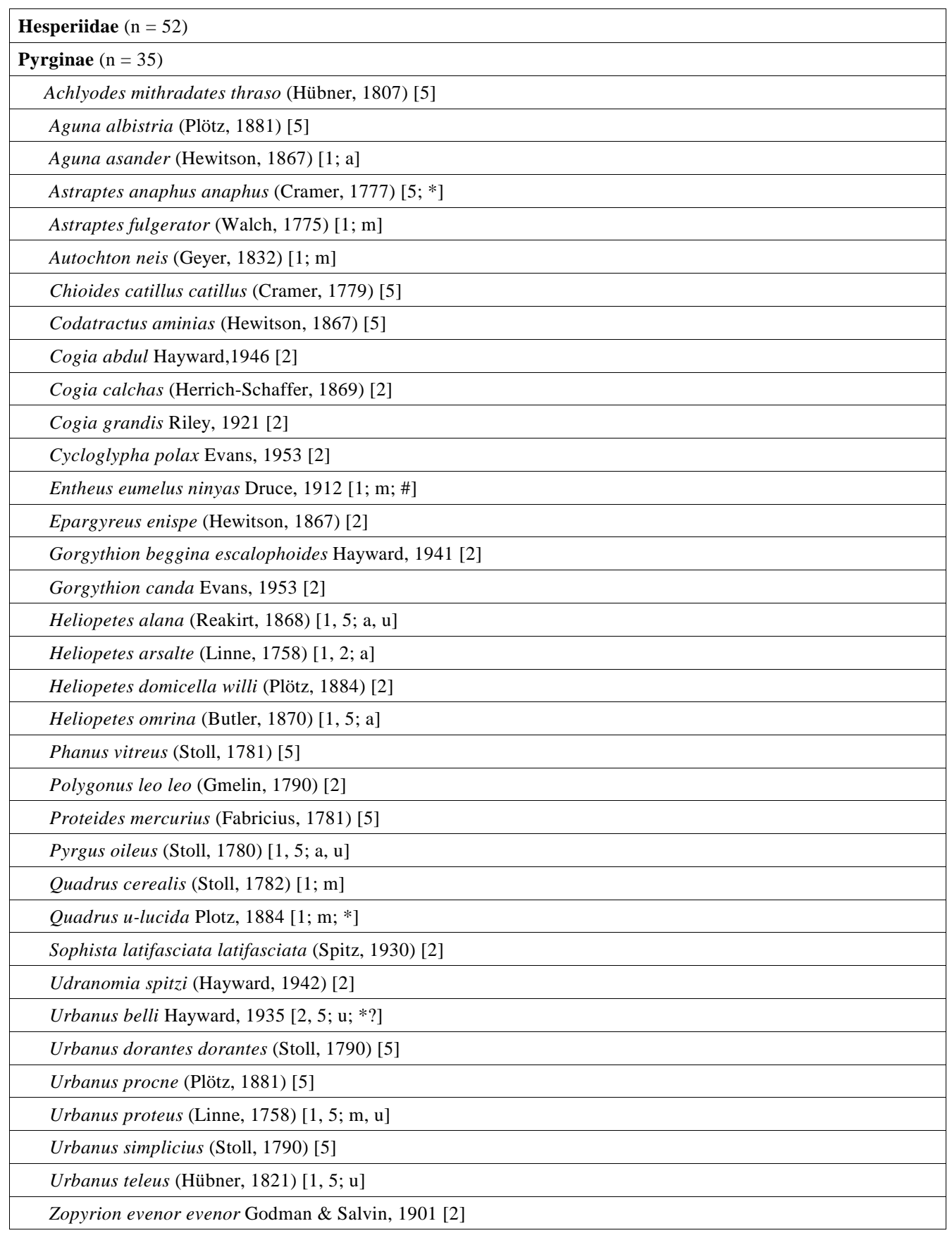




\section{TABLE 1 (Continued)}

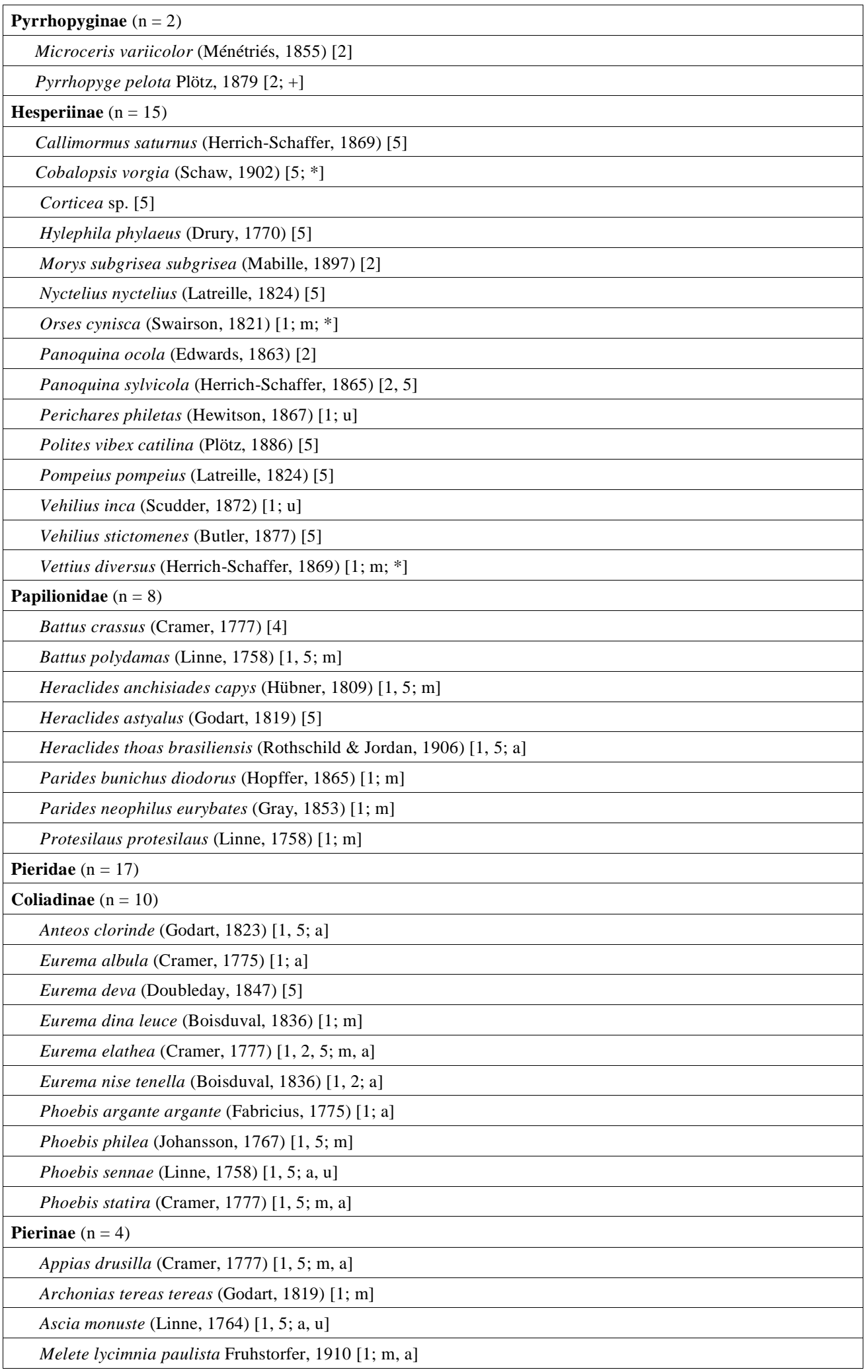




\section{TABLE 1 (Continued)}

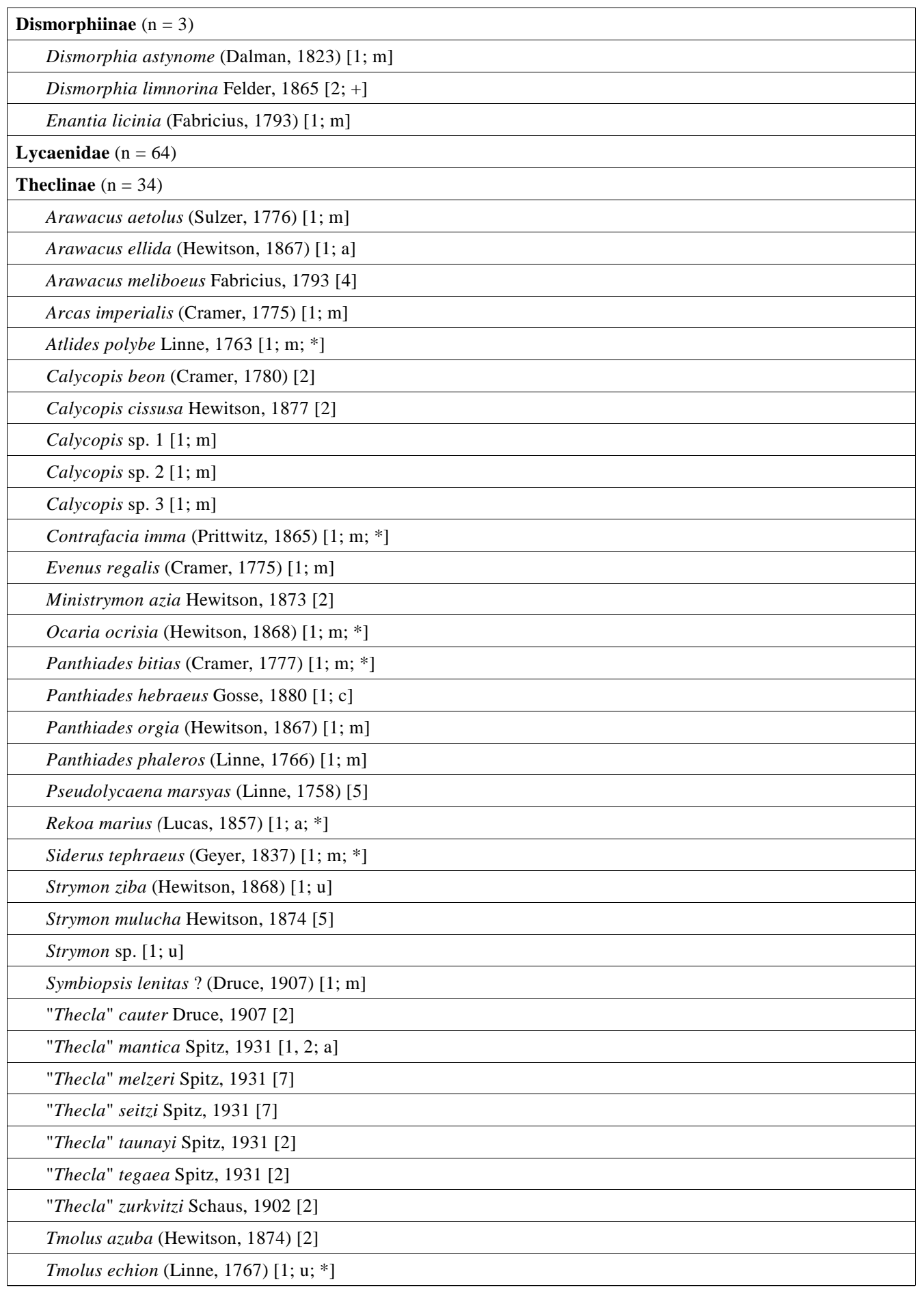




\section{TABLE 1 (Continued)}

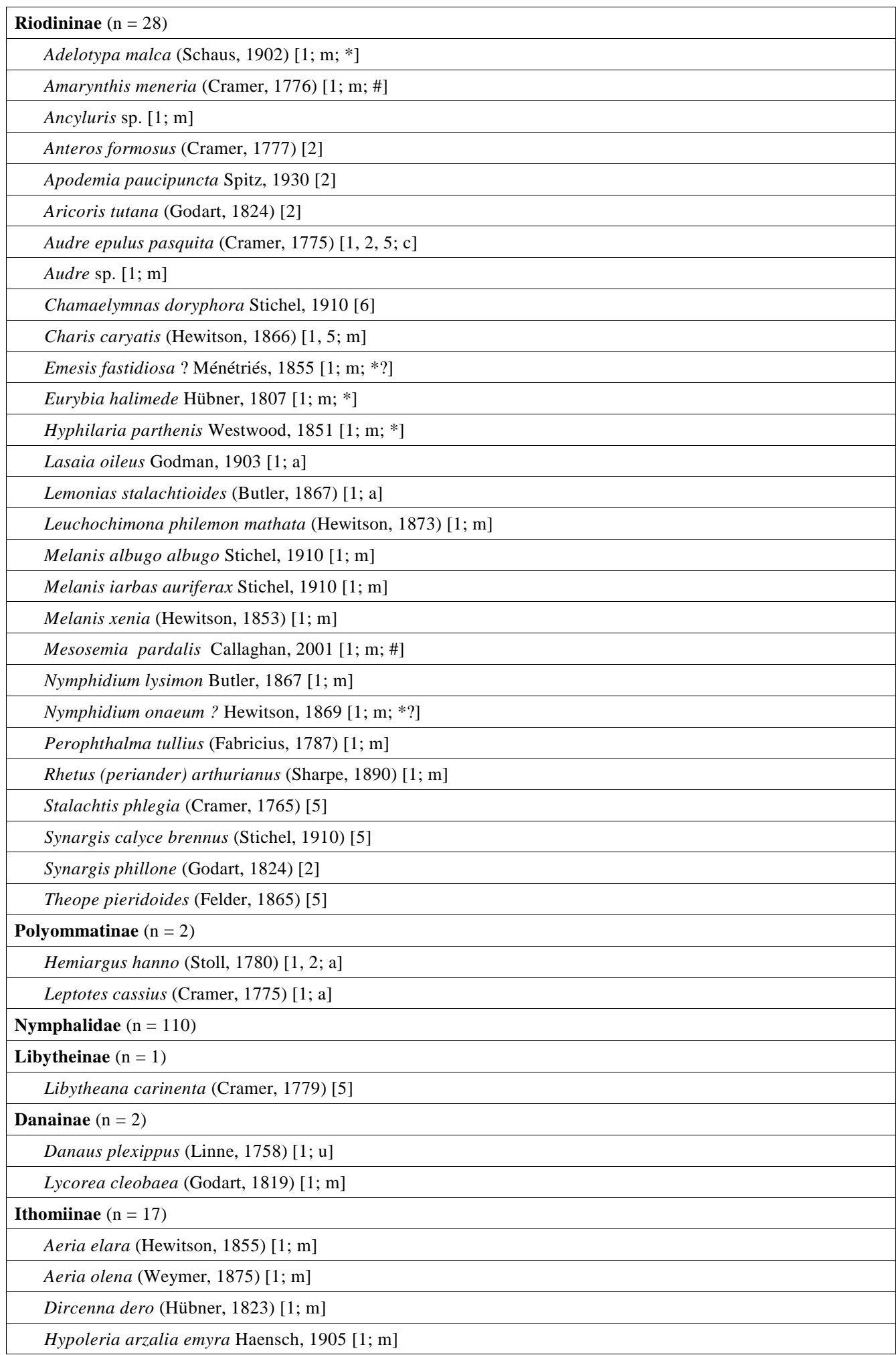


TABLE 1 (Continued)

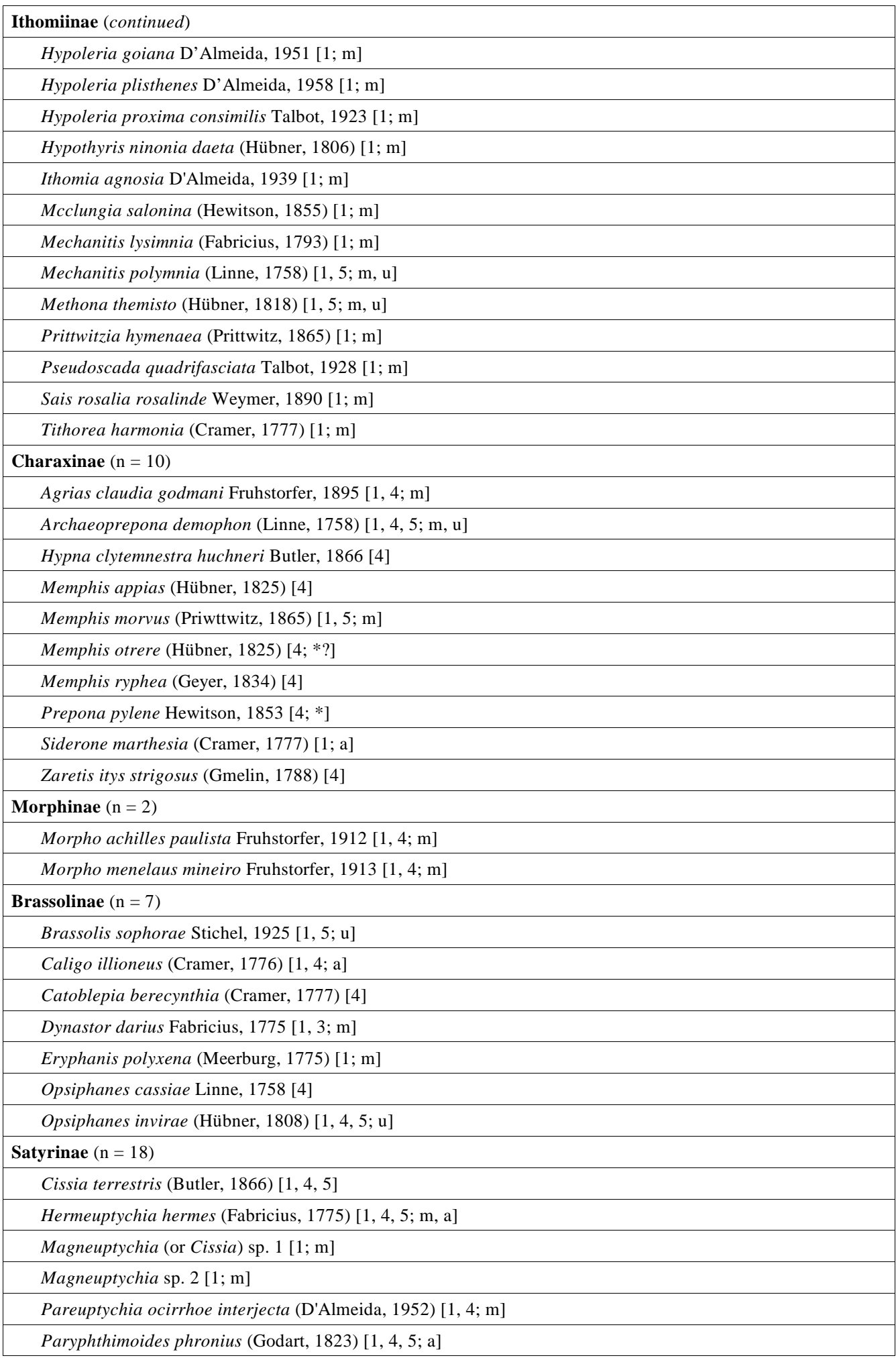




\section{TABLE 1 (Continued)}

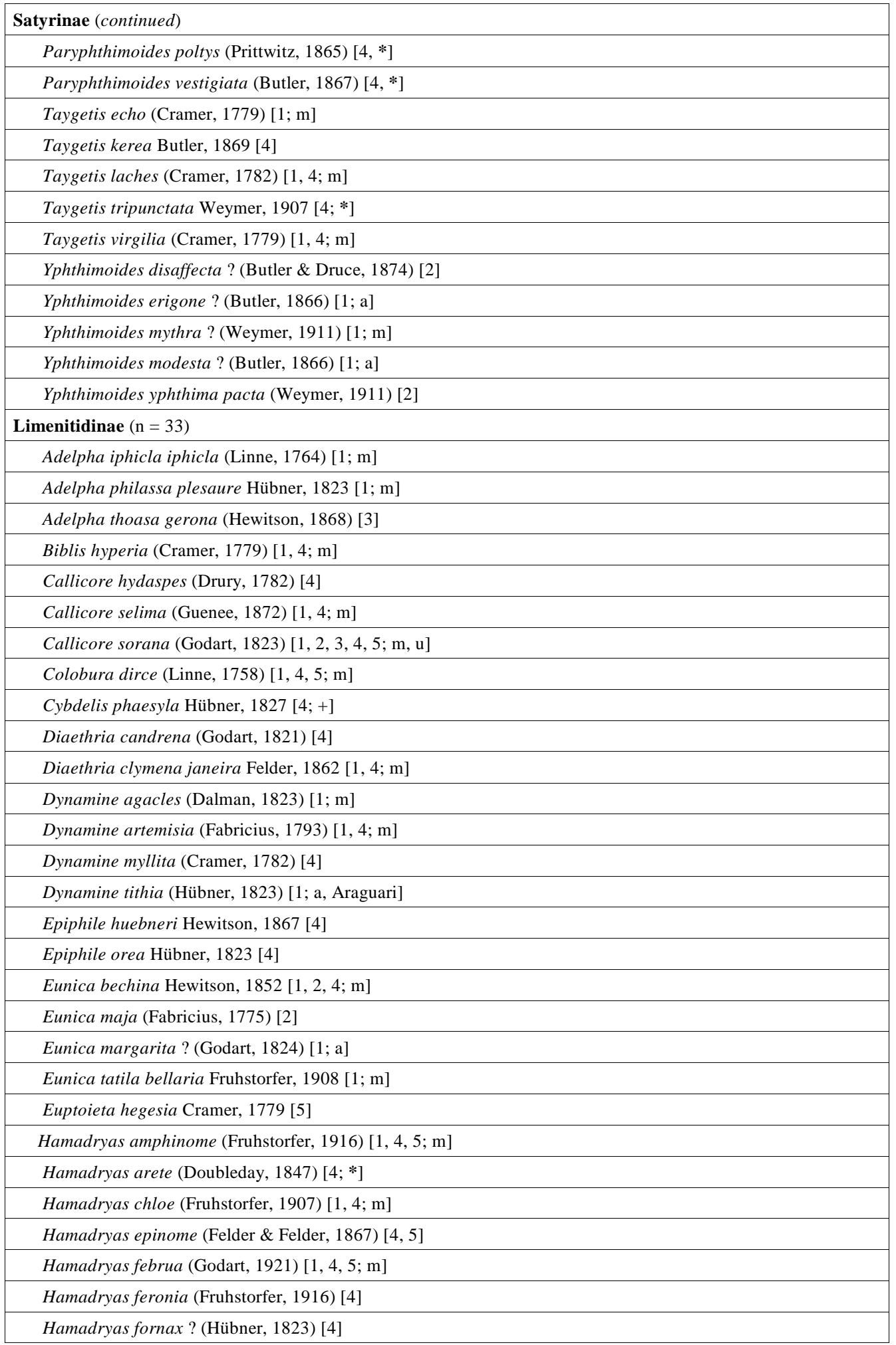


TABLE 1 (Continued)

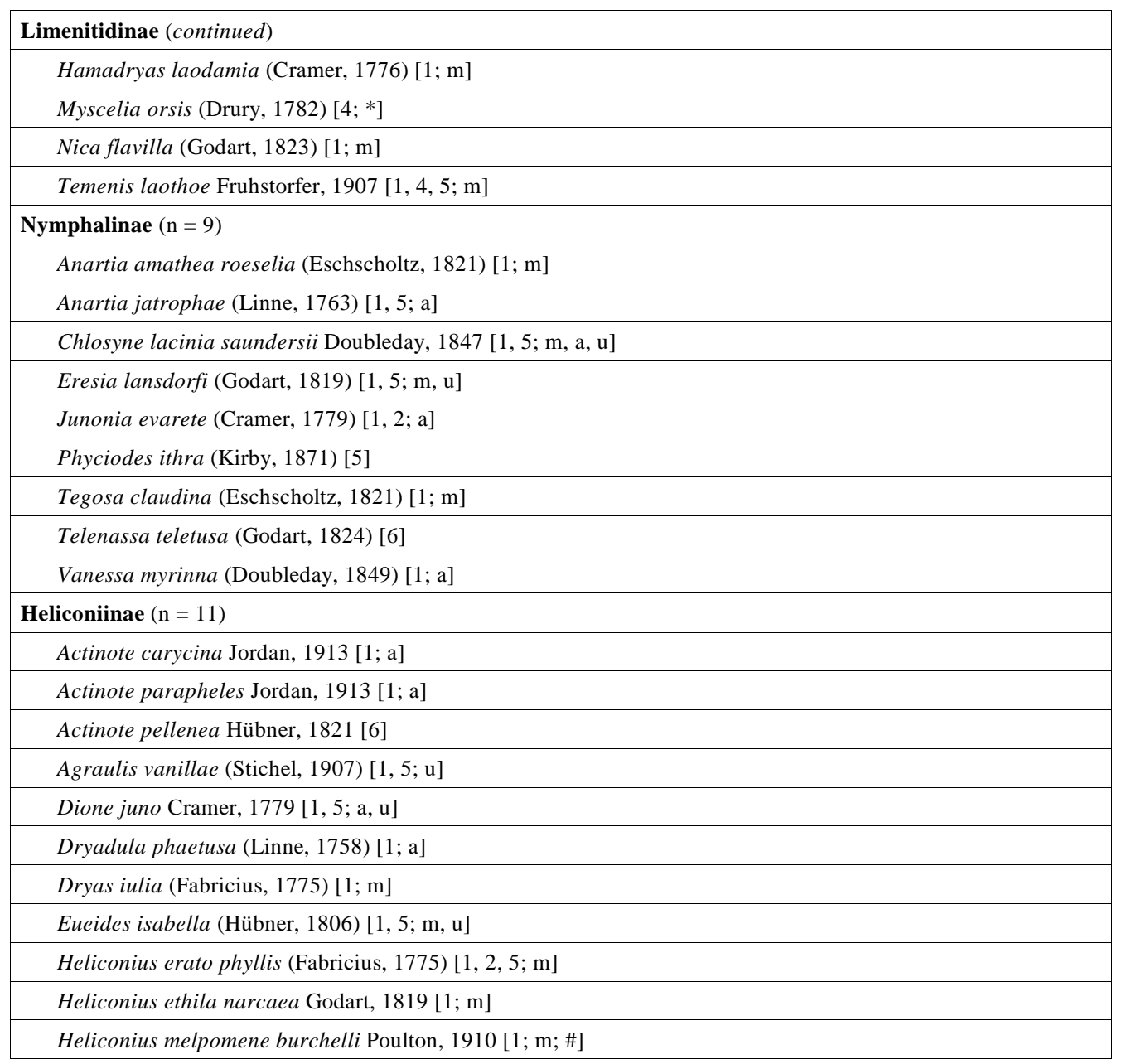

\section{Biogeographical comments}

There are many butterflies which are locally common and have wide distributions throughout Brazil, such as Eurema elathea, Phoebis sennae, Ascia monuste, Brassolis sophorae, Junonia evarete, Hamadryas amphinome, Agraulis vanillae, and Heliconius erato, which occur, for example, in Porto Alegre (RS), Campinas (SP), Uberlândia (MG), Brasília (DF), Rio de Janeiro (RJ), João Pessoa (PB), Belém (PA), Imperatriz (MA), and Araguaína (TO) (pers. obs.). However, little is known about the geographic distribution of the majority of Brazilian butterfly species.

Several Ithomiinae that occur in the Southeast (São Paulo, Campinas and Santos, for example) and Mid-west (Brasília) were not found in Uber- lândia, like Thyridia psidii (that occurs in Araxá, about $170 \mathrm{~km}$ to the southeast of Uberlândia), Hypothyris euclea, Oleria aquata, Placidula euryanassa, Heterosais edessa, and Pteronymia carlia.

On the other hand, Methona themisto occurs in all of these locations. However, the Uberlândia population, like those of other nearby cities to the north and west, presents a great degree of larval phenotypic diversity, indicating that this is as a hybridizing zone for populations of the southeast and others of the Central Plateau (Motta, 1998).

One example of a distribution boundary region is that of Aeria olena and A. elara. In the southeast, only A. olena occurs, being common in forests of São Paulo (Campinas, for example). 
In Uberlândia, two species occur, but $A$. elara is more abundant, while in Brasília, A. elara is common and A. olena is extremely rare.

Mesosemia pardalis is considered a rare species (K. Brown, pers. comm.; Callaghan, 2001), even though it is very abundant in the Glória forest, perhaps being endemic to this region.

Sais rosalia (Ithomiinae) and Protesilaus protesilaus (Papilionidae) were recorded only once during these four years, with the latter being detected because of a right front wing found on the forest floor.

At least in relation to the Ithomiinae, the region of Uberlândia appears to be an area constituting a distribution limit for some species, or of disjunct distributions, as well as intergrading or isolation of populations from the west, north and southeast of Brazil, and comprising a peripheral region of one of the areas known as an endemism center or "paleoecological refuge" for butterflies (Brown, 1977; 1982; 1987) and plants (Prance, 1982; 1987; 1996).

\section{Seasonality, interactions with plants and predation of butterflies in the Gloria forest}

The most abundant species during the dry season were Aeria elara, A. olena, Hypothyris ninonia, Mechanitis polymnia, M. lysimnia, Heliconius erato and Mesosemia pardalis. In the rainy season, the most abundant species were Morpho achilles, Parides neophilus, and Archonias tereas.

In regard to the Ithomiinae, in the dry season the populations increased and, from the middle of July until mid-September, individuals aggregated in moist areas of the forest, a behavior known as "pocket formation" (Brown \& Benson, 1974).

In the study area (Glória forest fragment), the pocket presented a high concentration of 16 species of Ithomiinae, along with some species from other groups. The rainy season, considered a season of dispersion, showed low population densities.

Ovipositions were observed mainly in the rainy season, or at the end of the dry period (Table 2).

TABLE 2

Season preferred for oviposition for the most abundant species of butterflies in the Glória forest fragment.

\begin{tabular}{|l|l|c|c|c|c|c|c|c|c|c|c|c|}
\hline \multirow{2}{*}{ Species } & \multicolumn{7}{c|}{ Month } \\
\cline { 2 - 14 } & \multicolumn{3}{|c|}{ Rainy } & \multicolumn{7}{c|}{ Dry } & \multicolumn{3}{c|}{ Rainy } \\
\hline & 1 & 2 & 3 & 4 & 5 & 6 & 7 & 8 & 9 & 10 & 11 & 12 \\
\hline Aeria elara & & & $\times$ & $\times$ & & & & & $\times$ & $\times$ & & \\
\hline Aeria olena & & & $\times$ & $\times$ & & & & & $\times$ & $\times$ & & \\
\hline Hypothyris ninonia & & & & $\times$ & & & & & $\times$ & & & \\
\hline Mechanitis polymnia & & & & $\times$ & & & & & $\times$ & & & \\
\hline Mechanitis lysimnia & & & & $\times$ & & & & & $\times$ & & & \\
\hline Heliconius erato & & & & $\times$ & & & & & & $\times$ & & \\
\hline Morpho achilles & & & & $\times$ & & & & & & $\times$ & $\times$ & \\
\hline Parides neophilus & & & $\times$ & $\times$ & & & & & & & $\times$ & $\times$ \\
\hline Parides bunichus & & & $\times$ & & & & & & & & & \\
\hline Mesosemia pardalis & & & $\times$ & & & & & & & & & \\
\hline Eresia lansdorfi & & & & & $\times$ & & & & & & & \\
\hline Heliconius ethila & & & & & & & & & & & & $\times$ \\
\hline
\end{tabular}


Only a few host plants were recorded: Aeria olena and A. elara used Prestonia acutifolia (Apocynaceae), Parides neophilus eurybates, Aristolochia sp.; Mechanitis and Hypothyris, Solanum gemellum; Hypoleria spp. used Cestrum spp. The flowers most visited by the species listed in Table 2 were Stachytarpheta polyura (Verbenaceae) from November until March, Eupatorium maximiliani (Asteraceae) from May to June, Vernonia sp. (Asteraceae) in June and July, and Psychotria prunifolia (Rubiaceae) from October to November. Perhaps the principal predators of adult butterflies are birds. An indirect means of evaluating this kind of mortality is through the wings found on the soil or litter (Table 3 ), generally with beak marks.

TABLE 3

Number of individuals (N) preyed upon by birds and the months (1 through 12) in which the wings were found on the ground. Arctiidae, Castniidae, Noctuidae, and Saturniidae are moths.

\begin{tabular}{|c|c|c|c|c|}
\hline Family & Subfamily & Species & $\mathbf{N}$ & Month \\
\hline \multirow[t]{2}{*}{ Papilionidae } & & Parides neophilus eurybates & 1 & 6 \\
\hline & & Protesilaus protesilaus & 1 & 10 \\
\hline \multirow[t]{5}{*}{ Pieridae } & \multirow[t]{3}{*}{ Coliadinae } & Anteos clorinde & 2 & 7,9 \\
\hline & & Phoebis philea & 2 & 4,5 \\
\hline & & Phoebis statira & 1 & 9 \\
\hline & Dismorphinae & Dismorphia astynome & 1 & 12 \\
\hline & Pierinae & Melete lycimnia paulista & 2 & 5,6 \\
\hline \multirow[t]{8}{*}{ Lycaenidae } & \multirow[t]{6}{*}{ Theclinae } & Atlides polybe & 1 & 11 \\
\hline & & Arcas imperialis & 1 & 4 \\
\hline & & Contrafacia imma & 1 & 12 \\
\hline & & Evenus regalis & 1 & 12 \\
\hline & & Ocaria ocrisia & 1 & 6 \\
\hline & & Panthiades bitias & 3 & $5,7,9$ \\
\hline & \multirow[t]{2}{*}{ Riodinidae } & Hyphilaria parthenis & 1 & 4 \\
\hline & & Leucochimona mathata & 1 & 7 \\
\hline \multirow[t]{12}{*}{ Nymphalidae } & \multirow[t]{5}{*}{ Ithomiinae } & Dircenna dero & 2 & 7,9 \\
\hline & & Hypothyris ninonia & 1 & 4 \\
\hline & & Mechanitis lysimnia & 2 & 9 \\
\hline & & Mechanitis polymnia & 2 & 7,9 \\
\hline & & Tithorea harmonia & 1 & 6 \\
\hline & Charaxinae & Archaeoprepona demophon & 1 & 10 \\
\hline & \multirow[t]{2}{*}{ Morphinae } & Morpho achilles paulista & 10 & $5,8,9,10$ \\
\hline & & Morpho menelaus mineiro & 5 & $4,7,8,9$ \\
\hline & \multirow[t]{3}{*}{ Limenitidinae } & Callicore selima & 3 & $3,6,7$ \\
\hline & & Diaethria clymena & 1 & 7 \\
\hline & & Hamadryas amphinome & 1 & 7 \\
\hline & Heliconiinae & Heliconius erato & 1 & 9 \\
\hline \multirow[t]{2}{*}{ Noctuidae } & & Catacalinae sp. 1 & 1 & 10 \\
\hline & & Catacalinae sp. 2 & 1 & 11 \\
\hline Castniidae & & Castnia laura & 1 & 3 \\
\hline Arctiidae & & Eucyane bicolor & 1 & 5 \\
\hline Saturniidae & & Automeris ca. illustris & 1 & 9 \\
\hline
\end{tabular}


The majority of individuals (63\%) were found in the dry season, but this does not necessarily indicate greater predation intensity for this period, because the wings are more easily seen in this period.

Morpho spp., the large and famous iridescent blue butterflies, were the most commonly preyed upon (15 individuals).

Orb web spiders are also potential predators of small and medium-sized butterflies.

The most abundant spiders in the area were Araneus sp., Gasteracantha cancriformes, Micrathena plana, Nephila clavipes, and Parawixia kocki.

The funnel web spider, Aglaoctenus lagotis (Lycosidae), was also very common in the area, but is probably not an important predator of butterflies due to the kind of web it weaves.

\section{General considerations}

The number of species (251) may be considered low, when compared with other regions of the country, although it is difficult to make comparisons due to differences in methodology, area sampled, and habitat type.

For example, in the Serra do Japi (Jundiaí, SP) and Linhares (forest reserve, ES) 652 and 680 species were recorded, respectively (Brown, 1992).

Most likely, the butterflies collected represent about $50 \%$ of the regional total, since the principal habitat (cerrado, in the strict sense) was undersampled.

Collections in open, riverside, and wetland areas, and the use of bait should increase the number of species.

Hesperiidae and Lycaenidae are families which should represent a much greater number of species.

As the sampling was mostly in dry forest, there should not be a substantial increase in the number of species recorded in this type of vegetation.

To maintain the diversity of butterflies, as well as of other animals, their interactions, and specified areas, it is essential that areas of forest, cerrado, wetlands, and palm veredas are preserved in Uberlândia and surrounding region.

The rapid expansion of urban areas tends to drastically decrease wildlife populations, driving some or many to extinction.
Acknowledgments - Dr. Keith S. Brown Jr. (Universidade Estadual de Campinas) patiently identified the collected species and provided much information about them. Many thanks to my friends Alexandre Ruszczyk, Vanessa B. M. Galassi Spini, Hamilton Garcia Jr., and Élvis Souza Nascimento for their companionship and help in the field. Marc A. Johnson translated the manuscript from Portuguese. Dr. K. Brown Jr. and Dr. A. Ruszczyk read drafts of the manuscript and furnished many helpful comments. The Departamento de Biociências da Universidade Federal de Uberlândia provided logistic and institutional support.

\section{REFERENCES}

ARAÚJO, A. F. B., FERREIRA, D. C. \& SILVA, E. A., 1987 Borboletas da mata do Carrinho, Uberaba, Minas Gerais. An. Semin. Ci. Fiube, 1: 55-76.

ARAÚJO, G. M. \& HARIDASAN, M., 1997, Estrutura fitossociológica de duas matas mesófilas semidecíduas em Uberlândia, Triângulo Mineiro. Naturalia, 22: 115-129.

BROWN Jr., K. S., 1977, Centros de evolução, refúgios quaternários e conservação de patrimônios genéticos na região neotropical: padrões de diferenciação em Ithomiinae (Lepidoptera: Nymphalidae). Acta Amaz., 7: 75-137.

BROWN Jr., K. S., 1982, Paleoecology and regional patterns of evolution in neotropical forest butterflies. In: G. T. Prance (ed.), Biological diversification in the tropics. Columbia University Press, New York, pp. 255-308.

BROWN Jr., K. S., 1987, Biogeography and evolution of neotropical butterflies. In: T. C. Whitmore \& G. T. Prance (eds.), Biogeography and quaternary history in tropical America. Clarendon Press, Oxford, pp. 66-105.

BROWN Jr., K. S., 1992, Borboletas da Serra do Japi: diversidade, habitats, recursos alimentares e variação temporal In: L. P. C. Morellato (ed.), História natural da Serra do Japi, ecologia e preservação de uma área florestal no Sudeste do Brasil. Editora da UNICAMP/FAPESP, Campinas, pp. 142-186.

BROWN Jr., K. S. 1996a, Conservation of threatened species of Brazilian butterflies. In: S. A. Ae, T. Hirowatari, M. Ishii \& L. P. Brower (eds.), Decline and conservation of butterflies in Japan. Lepidop. Society of Japan, Yadoriga, Osaka, pp: 45-62 (special issue).

BROWN Jr., K. S. 1996b, Diversity of Brazilian Lepidoptera: history of study, methods for measurement, and use as indicator for genetic, specific and system richness. In: C. E. M. Bicudo \& N. A. Menezes (eds.), Biodiversity in Brazil, a first approach. Instituto de Botânica/CNPq, São Paulo, pp. 221-253.

BROWN Jr., K. S. 1996c, The use of insects in the study, inventory, conservation and monitoring of biological diversity in Neotropical habitats, in relation to traditional land use systems. In: S. A. Ae, T. Hirowatari, M. Ishii \& L. P. Brower (eds.), Decline and conservation of butterflies in Japan. Lepidop. Society of Japan, Yadoriga Osaka, pp: 128-149 (special issue). 
BROWN Jr., K. S. 1997, Diversity, disturbance, and sustainable use of Neotropical forests: insects as indicators for conservation monitoring. Journ. Insect. Conserv., 1: $25-42$.

BROWN Jr., K. S. \& BENSON, W. W., 1974, Adaptive polymorphism associated with multiple Müllerian mimicry in Heliconius numata (Lepidoptera: Nymphalidae). Biotropica, 6: 205-228

BROWN Jr., K. S. \& BROWN, G. G., 1992, Habitat alteration and species loss in Brazilian forests. In: T. C. Whitmore \& J. A. Sayer (eds.), Tropical deforestation and species extinction. Chapman \& Hall, London, pp. 119-142.

BROWN Jr., K. S. \& MIELKE, O. H. H., 1967a, Lepidoptera of Central Brazil Plateau. I. Preliminary list of Rhopalocera: Introduction, Nymphalidae, Libytheidae. J. Lepid. Soc., 21: 77-106.

BROWN Jr., K. S. \& MIELKE, O. H. H., 1967b, Lepidoptera of Central Brazil Plateau. I. Preliminary list of Rhopalocera (continued): Lycaenidae, Pieridae, Papilionidae, Hesperiidae. J. Lepid. Soc., 21: 145-168.

CALlaghan, C. J., 2001, New riodinids from the Central Brazilian plateau (Lepidoptera, Riodinidae). Rev. Bras. Zool., 18: 765-778.

DeVRIES, P. J., 1987, The butterflies of Costa Rica and their natural history. Princeton University Press, Princepton, $327 \mathrm{p}$.

HARVEY, D. J., 1991, Higher classification of the Nymphalidae, Appendix B. In: H. F. Nijhout, The development and evolution of butterfly wing patterns. Smithsonian Inst. Press, Washington, pp. 255-273.

MIELKE, O. H. H. \& CASAGRANDE, M. M., 1988, Sobre os tipos de Lepidoptera depositados em museus brasileiros. XVI. Hesperiidae, Satyridae, Lycaenidae, Riodinidae, Castniidae e Arctiidae descritos por Roberto Spitz. Revta. Bras. Ent., 32: 3-6.
MOTTA, P. C., 1998, Estudos macro e microevolutivos nas borboletas Ithomiinae (Nymphalidae). Tese de Doutorado, Universidade Estadual de Campinas, São Paulo.

NEW, T. R., PYLE, R. M., THOMAS, J. A., THOMAS, C. D. \& HAMMOND, P. C., 1995, Butterfly conservation management. Ann. Rev. Entomol., 40: 57-83.

PRANCE, G. T., 1982, Forest refuges: evidence from woody angiosperms. In: G. T. Prance (ed.), Biological diversification in the tropics. Columbia University Press, New York, pp. 137-158.

PRANCE, G. T., 1987, Biogeography of neotropical plants. In: T. C. Whitmore \& G. T. Prance (eds.), Biogeography and Quaternary History in Tropical America. Clarendon Press. Oxford, pp. 46-65.

PRANCE, G. T., 1996, Islands in Amazonia. Phil. Trans. Roy. Soc. Lon., B, 351: 823-833.

ROSA, R. S., LIMA, M. \& ASSUNÇÃO, W. L., 1991, Abordagem preliminar das condições climáticas de Uberlândia (MG). Soc. \& Nat., 3(5-6): 91-108.

RUSZCZYK, A. \& SILVA, C. F., 1997, Butterflies select microhabitats on building walls. Lands. Urban Plann., 38: 119-127.

SBORDONI, V. \& FORESTIERO, S., 1985, Butterflies of the world. Crescent Books, New York, 312p.

SCOTT, J. A., 1985, The phylogeny of butterflies (Papilionoidea e Hesperioidea). J. Res. Lepid., 23: 241-281.

SOLIS, M. A. \& POGUE, M. G., 1999, Lepidopteran biodiversity: patterns and estimators. Amer. Entom., 45: 206212.

TYLER, H. A., BROWN Jr., K. S. \& WILSON, K. H., 1994, Swallowtail butterflies of the Americas: a study in biological dynamics, ecological diversity, biosystematics, and conservation. Scientific Publishers, Gainesville, 376p. 